\title{
Effect of Biofertilizers, Levels of Nitrogen and Zinc on Growth and Yield of Hybrid Maize (Zea mays L.)
}

\author{
Evangeline Marngar* and Joy Dawson \\ Department of Agronomy, Sam Higginbottom University of Agriculture, Technology and \\ Sciences, Allahabad 211007, U.P., India \\ *Corresponding author
}

A B S T R A C T

\begin{tabular}{|l|}
\hline Ke y w or d s \\
Nitrogen, zinc, \\
Azotobacter, \\
Azospirillum \\
\hline Article Info \\
\hline Accepted: \\
10 July 2017 \\
Available Online: \\
10 September 2017 \\
\hline
\end{tabular}

The experiment consisted of three levels of nitrogen $(90,120$ and $150 \mathrm{~kg} \mathrm{ha}$ ${ }^{1}$ ) with basal application of $\mathrm{P}_{2} \mathrm{O}_{5}$ and $\mathrm{K}_{2} \mathrm{O}$ each at $60 \mathrm{~kg} \mathrm{ha}^{-1}$ and zinc at $15 \mathrm{~kg} \mathrm{ha}^{-1}$ (basal application) or $0.5 \% \mathrm{ZnSO}_{4}$ (foliar spray) and inoculated with Azotobacter or Azospirillum. Highest number of cobs plant ${ }^{-1}$, plant height, dry weight, grains $\mathrm{cob}^{-1}$ and grain yield was recorded in the plots treated with $150 \mathrm{~kg} \mathrm{ha}^{-1} \mathrm{~N}+15 \mathrm{~kg} \mathrm{ZnSO}_{4}$ basal along with seed inoculation with Azospirillum $20 \mathrm{~g}$ per kg seeds.

\section{Introduction}

Maize (Zea mays L) is one of the most versatile emerging crops having wider adaptability under varied agro-climatic conditions. Globally, maize is known as "queen of cereals" because it has the highest genetic yield potential among the cereals. Maize is one of the important cereal crops next to wheat and rice in the world. The productivity of maize mainly depends on its nutrient management (Kumar et al., 2007). Being a $\mathrm{C} 4$ plant, maize is capable of utilizing solar radiation more efficiently compared to other cereals. Maize is grown throughout the year in all states of the country for various purposes including fodder for animals, food grain, sweet corn, baby corn, green cobs and popcorn, corn flour is consumed widely in Indian cooking.
Among the cereals in India, maize occupies the third most important food crops after rice and wheat. In order to obtain more agricultural production, either more lands should be cultivated, which is not applicable in most cases, or higher yield must be produced in the currently cultivated lands.

One way is using inoculants of microorganisms which provide many nutrients to plants; Azotobacter and Azospirillum are the two examples of these microorganisms. Mycorrhizal symbiosis increases absorption of some elements such as phosphorus, nitrogen and micronutrients, improves water uptake, produces hormones, reduces damages caused by environmental stress, improves quality of soil aggregate. 
Azotobacter is a beneficial free living (nonsymbiosis) nitrogen fixing bacteria which is reported to fix $20-60 \mathrm{~kg} / \mathrm{ha}$ nitrogen in soil annually. Azotobacter was the first and is the most common biofertilizer for some plants such as maize, wheat, sorghum and rice which produces some plant growth promoting metabolites, enzymes and hormones (auxin, cytokinin and gibberelin) in addition to fixing air nitrogen (Forlain et al., 1998).

Nitrogen is an essential element for both fodder quantity and quality as it is a component of protein and chlorophyll. It is thus, essential for photosynthesis, vegetative and reproductive growth and it often determines yield of maize (Iqbal et al., 2006). Both the yield and quality of maize are strongly influenced by the availability of nitrogen.

Application of micronutrient also play significant role in improvement of grain yield of maize. Among micronutrient zinc plays an important role in photosynthesis, nitrogen metabolism and regulates auxin concentration in the plant. The $\mathrm{Zn}$ deficiency was found wide spread in Indian soil. Zinc is most crucial amongst the micronutrients that take part in plant growth and development due to its catalytic action in metabolism of almost all crops (George and Schmitt, 2002). However, micronutrients can be applied directly into the soil as well.

\section{Materials and Methods}

The experiment was conducted at the Crop Research Farm, Department of Agronomy, Naini Agricultural Institute, Sam Higginbottom University of Agriculture, Technology and Sciences, Allahabad during the Kharif season of 2016. The soil of the experimental field was sandy loam in texture, acidic in reaction ( $\mathrm{pH} 7.2$ ), low in organic carbon $(0.44 \%)$, low in available nitrogen $\left(0.99 \mathrm{~kg} \mathrm{ha}{ }^{-1}\right)$, medium in available phosphorus (22.5 $\left.\mathrm{kg} \mathrm{ha}{ }^{-1}\right)$ and high in potassium (347 kg ha ${ }^{-1}$ ). The experiment consisted of twelve treatment combinations of three levels of nitrogen $(90,120$ and $150 \mathrm{~kg}$ ha-1), two different biofertilizers (Azotobacter seed inoculation and Azospirillum seed inoculation), basal application of zinc (15 kg ha-1) and zinc foliar application $(0.5 \%)$ with three splits of nitrogen, phosphorus and potassium (each $60 \mathrm{~kg} \mathrm{ha}^{-1}$ ) given in basal form. The experiment was laid out in Randomnized Block Design and replicated three times. Zinc in the form of $\mathrm{ZnSO}_{4}$ was applied as basal before sowing of the crop. Recommended dose of nitrogen (120 kg ha $\left.{ }^{-1}\right)$ as per the treatments was calculated for each plot using urea, along with uniform dose of phosphorus $\left(60 \mathrm{~kg} \mathrm{ha}^{-1}\right)$ through diammonium phosphate and potash $\left(60 \mathrm{~kg} \mathrm{ha}^{-1}\right)$ through muriate of potash were applied in flat bed a day before sowing of the crop at 5-6 cm depth. One half of the nitrogen along with full dose of phosphorus and potash according to the treatment were applied as basal dose. The remaining half dose of nitrogen was top dressed into equal splits at knee high stage and tasseling stage. The hybrid maize seed "MM 2255" has very early maturity (85 days duration) and sown where seeds were placed at 3-4 cm depth at a spacing of $60 \mathrm{~cm}$ between rows and $20 \mathrm{~cm}$ between plants. One to two seeds were planted at each hill and covered with soil. The seeds were treated with Azotobacter and Azospirillum inoculant as per the treatment. The seeds were thoroughly mixed with biofertilizer slurry in such a way that all the seeds were uniformly coated with biofertilizer then allowed to dry in the shade before sowing of the crop.

\section{Results and Discussion}

\section{Growth indices of hybrid maize}

Maximum plant height was found in treatment receiving seed inoculation of Azospirillum $+150 \mathrm{~kg} \mathrm{ha}^{-1} \mathrm{~N}+15 \mathrm{~kg} \mathrm{ha}^{-1} \mathrm{Zn}$ 
$\left(\mathrm{T}_{6}\right)$ at $60 \mathrm{DAS}$ recording $148.23 \mathrm{~cm}$ and was found to be at par with the application Azotobacter $+150 \mathrm{~kg} \mathrm{ha}^{-1} \mathrm{~N}+0.5 \% \mathrm{Zn}\left(\mathrm{T}_{9}\right)$ and Azospirillum $+150 \mathrm{~kg} \mathrm{ha}^{-1} \mathrm{~N}+0.5 \% \mathrm{Zn}$ $\left(\mathrm{T}_{12}\right)$ as shown in Table 1. The application of nitrogen fertilizer level with increasing levels has significantly increased the plant height due to the positive effect of nitrogen element on plant growth. Similar finding was reported by Asif et al., (2013) where there is significant effect of $\mathrm{N}$ and $\mathrm{Zn}$ observed in maize which attributed to more vegetative development that resulted in increased mutual shading and intermodal extension. Nitrogen is vital as it is the main component of chlorophyll, amino acids and building blocks of protein. Providing adequate nitrogen allows the crop to grow to full maturity rather than delaying it. Increase in plant height in response to higher $\mathrm{N}$ levels has also been confirmed by Akbar et al., (2002) and Rasheed et al., (2004). According to the findings of Braccini et al.,(2012) inoculation treatments of maize seeds with liquid Azospirillum brasilense also cause an increase in the height of plants. According Puente et al., (2009), the inoculation with the optimal bacterial concentration of Azospirillum increased plant height. Similar findings by Sharma (1973) was reported addition of nitrogen fertilizer increased the plant height. The findings are in full agreement with that of Sawi (1993) and Omara (1989) who observed that nitrogen had significant effects on plant height.

Highest number of plant leaves were observed in treatment $\mathrm{T}_{6}$ (Azospirillum $+150 \mathrm{~kg} \mathrm{ha}^{-1} \mathrm{~N}$ $+15 \mathrm{~kg} \mathrm{ha}^{-1} \mathrm{Zn}$ ) which was found to be statistically at par with $\mathrm{T}_{3}$ and $\mathrm{T}_{9}$. At $60 \mathrm{DAS}$ it was found to be statistically at par with treatments $T_{3}$ and $T_{9}$. Nitrogen fertilization increased number of leaves per plant and leaf area (El Noeman et al.,1990: Gasim, 2001).The findings are in full agreement with that of Sawi (1993) and Omara (1989) who reported that nitrogen had significant effects on chemical composition of leaves, leaves, internodes number per plant at early stages.

Similarly maximum dry weight at 60 DAS was received in treatment $\mathrm{T}_{6}(23.10 \mathrm{~g})$ and it was found that $\mathrm{T}_{12}(23.00 \mathrm{~g})$ was found to be significant and is statistically at par with treatment $\mathrm{T}_{6}$. The results were similar with the findings by Cohen et al., (1980) which showed that inoculation of plants with Azospirillum showed significant increase of root and dry shoot dry weight reported in Maize. Carlettie (2002) reported that Azotobacter fixes air nitrogen and produces plant growth promoters with increase in plant growth and the number of hair roots and plants take up more water and nutrients. Azotobacter fixes air nitrogen and produces plant growth promoters with increase in plant growth and the number of hair roots and plants take up more water and nutrients. These results were similar with findings by Carlettie (2002). The results were also similar with findings by Cohen et al., (1980) who reported that Azospirillum inoculated plants showed significant increases of root and shoot dry weight of plants in maize. Braccini et al., (2012) found that inoculation of maize seeds with Azospirillum brasilense also causes a significant increase in the plants' dry matter. According to Puente et al., (2009), the inoculation with the optimal bacterial concentration of Azospirillum increased root length and root and aerial dry weight.

Increase in soil nitrogen through fixation by inoculation of Azotobacter has increased the crop growth as found by Monib et al., (1979). According to Fallik et al., (1988) the enhancement of root and shoot in Zea mays were observed under controlled conditions. Although only relatively small amounts of fertilizers are required during the very early stages of plant growth, high concentration of nutrients in the root zone at that time are beneficial in promoting early growth (Ritchie et al., 1993). 
Table.1 Effect of different Biofertilizers, Zinc and Nitrogen levels in Hybrid Maize

\section{At 60 DAS}

Treatments

\begin{tabular}{|c|c|c|c|}
\hline $\begin{array}{l}\text { Plant height } \\
\quad(\mathrm{cm})\end{array}$ & $\begin{array}{c}\text { Leaves/plant } \\
\text { (No.) }\end{array}$ & $\begin{array}{c}\text { Dry weight } \\
\text { (g/plant) }\end{array}$ & $\begin{array}{c}\text { CGR } \\
\left(\mathrm{g} \mathrm{m}^{-2} \mathrm{day}^{-1}\right)\end{array}$ \\
\hline 115.67 & 10.73 & 17.17 & 5.27 \\
\hline 121.40 & 10.67 & 18.10 & 5.08 \\
\hline 134.67 & 12.80 & 22.02 & 6.61 \\
\hline 127.00 & 10.53 & 18.20 & 5.53 \\
\hline 130.33 & 10.73 & 17.07 & 5.02 \\
\hline 148.23 & 13.67 & 23.10 & 6.79 \\
\hline 128.60 & 11.07 & 17.10 & 4.98 \\
\hline 133.13 & 10.87 & 19.00 & 5.79 \\
\hline 141.67 & 13.47 & 22.03 & 6.92 \\
\hline 111.35 & 10.87 & 19.07 & 5.42 \\
\hline 130.73 & 10.90 & 20.20 & 5.89 \\
\hline 140.00 & 11.10 & 23.00 & 6.92 \\
\hline$S$ & $S$ & $S$ & $S$ \\
\hline 6.32 & 0.86 & 0.13 & 0.22 \\
\hline 13.11 & 1.78 & 0.27 & 0.45 \\
\hline
\end{tabular}

Three splits of $\mathrm{N}$ and blanket dose of $\mathrm{P}_{2} \mathrm{O}_{5}$ at $60 \mathrm{~kg} \mathrm{ha}^{-1}$ and $\mathrm{K}_{2} \mathrm{O}$ at $60 \mathrm{~kg} \mathrm{ha}^{-1}$ 
Table.2 Effect of different Biofertilizers, Zinc and Nitrogen levels in Hybrid Maize

\begin{tabular}{|c|c|c|c|c|c|c|c|}
\hline \multirow{2}{*}{ Treatments } & \multicolumn{6}{|c|}{ At harvest } & \multirow[b]{2}{*}{$\begin{array}{l}\mathrm{B}: \mathrm{C} \\
\text { ratio }\end{array}$} \\
\hline & $\begin{array}{l}\text { Diameter } \\
\text { of cob }(\mathrm{cm})\end{array}$ & $\begin{array}{l}\text { Grain rows } \\
\mathrm{cob}^{-1}\end{array}$ & $\begin{array}{l}\text { No. of grains } \\
\operatorname{cob}^{-1}\end{array}$ & $\begin{array}{l}\text { Grain yield } \\
\text { (t/ha) }\end{array}$ & $\begin{array}{l}\text { Stover yield } \\
\text { (t/ha) }\end{array}$ & $\begin{array}{l}\text { Net return } \\
\left(\mathrm{Rs} \mathrm{ha}^{-1}\right)\end{array}$ & \\
\hline 1. Azotobacter $+90 \mathrm{~kg} / \mathrm{ha} \mathrm{N}+15 \mathrm{~kg} / \mathrm{ha} \mathrm{Zn}$ & 11.86 & 10.00 & 199.11 & 3.18 & 7.30 & 15403.00 & 1.45 \\
\hline 2. Azotobacter $+120 \mathrm{~kg} / \mathrm{ha} \mathrm{N}+15 \mathrm{~kg} / \mathrm{ha} \mathrm{Zn}$ & 11.96 & 12.67 & 218.89 & 3.71 & 8.70 & 23533.00 & 1.68 \\
\hline 3. Azotobacter $+150 \mathrm{~kg} / \mathrm{ha} \mathrm{N}+15 \mathrm{~kg} / \mathrm{ha} \mathrm{Zn}$ & 12.59 & 13.33 & 251.59 & 5.00 & 9.00 & 40333.00 & 2.16 \\
\hline 4. Azospirillum+90kg/ha N $+15 \mathrm{~kg} / \mathrm{ha} \mathrm{Zn}$ & 11.65 & 12.67 & 214.00 & 3.80 & 8.70 & 25003.00 & 1.73 \\
\hline 5. Azospirillum $+120 \mathrm{~kg} / \mathrm{ha} \mathrm{N}+15 \mathrm{~kg} / \mathrm{ha} \mathrm{Zn}$ & 12.09 & 13.33 & 244.86 & 5.00 & 9.20 & 40853.00 & 2.19 \\
\hline 6. Azospirillum $+150 \mathrm{~kg} / \mathrm{ha} \mathrm{N}+15 \mathrm{~kg} / \mathrm{ha} \mathrm{Zn}$ & 13.09 & 14.00 & 323.33 & 7.90 & 11.20 & 80453.00 & 3.32 \\
\hline 7. Azotobacter $+90 \mathrm{~kg} / \mathrm{ha} \mathrm{N}+0.5 \% \mathrm{Zn}$ & 12.13 & 11.33 & 233.53 & 4.10 & 8.40 & 32573.00 & 2.00 \\
\hline 8. Azotobacter $+120 \mathrm{~kg} / \mathrm{ha} \mathrm{N}+0.5 \% \mathrm{Zn}$ & 12.05 & 13.33 & 264.51 & 5.38 & 8.50 & 49023.00 & 2.61 \\
\hline 9. Azotobacter $+150 \mathrm{~kg} / \mathrm{ha} \mathrm{N}+0.5 \% \mathrm{Zn}$ & 12.16 & 14.00 & 282.33 & 6.10 & 9.20 & 61733.00 & 3.20 \\
\hline 10. Azospirillum $+90 \mathrm{~kg} / \mathrm{ha} \mathrm{N}+0.5 \% \mathrm{Zn}$ & 12.12 & 11.33 & 242.00 & 4.61 & 9.27 & 40160.00 & 2.34 \\
\hline 11. Azospirillum $+120 \mathrm{~kg} / \mathrm{ha} \mathrm{N}+0.5 \% \mathrm{Zn}$ & 12.21 & 12.00 & 319.31 & 6.60 & 9.57 & 66060.00 & 3.18 \\
\hline 12. Azospirillum $+150 \mathrm{~kg} / \mathrm{ha} \mathrm{N}+0.5 \% \mathrm{Zn}$ & 12.54 & 12.67 & 317.33 & 6.53 & 11.00 & 66423.00 & 3.17 \\
\hline F-test & NS & $\mathrm{S}$ & NS & $\mathrm{S}$ & $\mathrm{S}$ & & \\
\hline S.Ed. $( \pm)$ & 0.16 & 1.06 & 1.73 & 0.76 & 0.23 & & \\
\hline $\mathrm{C} \mathrm{D}(\mathrm{P}=0.05)$ & - & 2.20 & - & 1.58 & 0.48 & & \\
\hline
\end{tabular}

Three splits of $\mathrm{N}$ and blanket dose of $\mathrm{P}_{2} \mathrm{O}_{5}$ at $60 \mathrm{~kg} \mathrm{ha}^{-1}$ and $\mathrm{K}_{2} \mathrm{O}$ at $60 \mathrm{~kg} \mathrm{ha}^{-1}$ 
The data on cob diameter $(\mathrm{cm})$ as influenced by nitrogen management practices with biofertilizers and zinc are presented in Table 2 indicated that the cob diameter was found to be not significant among the other treatments. The highest cob diameter $(13.09 \mathrm{~cm})$ was found with the inoculation of Azospirillum + $150 \mathrm{~kg} \mathrm{ha}^{-1} \mathrm{~N}+15 \mathrm{~kg} \mathrm{ha}^{-1} \mathrm{Zn}\left(\mathrm{T}_{6}\right)$ and the minimum cob diameter $(11.65 \mathrm{~cm})$ was recorded with Azospirillum $+90 \mathrm{~kg} \mathrm{ha}^{-1} \mathrm{~N}+$ $15 \mathrm{~kg} \mathrm{ha}^{-1} \mathrm{Zn}\left(\mathrm{T}_{4}\right)$. Some researchers reported different and they found that nitrogen fertilizer application increased the cob diameter values (Kara et al., 1999; Saruhan and Sireli, 2005).

\section{Yield indices of hybrid maize}

\section{Grain rows per cob}

It is evident from the data presented in the Table 2 that grain rows $\mathrm{cob}^{-1}(\mathrm{~cm})$ was affected significantly by combination of biofertilizers, nitrogen and zinc. The highest grain row $(14 \mathrm{~cm})$ was recorded with the inoculation of Azospirillum $+150 \mathrm{~kg} \mathrm{ha}^{-1} \mathrm{~N}+$ $15 \mathrm{~kg} \mathrm{ha}^{-1} \mathrm{Zn}\left(\mathrm{T}_{6}\right)$ and remained at par to $\mathrm{T}_{2}$, $\mathrm{T}_{3}, \mathrm{~T}_{4}, \quad \mathrm{~T}_{5}, \quad \mathrm{~T}_{6}, \mathrm{~T}_{7}, \mathrm{~T}_{8}, \mathrm{~T}_{10}, \mathrm{~T}_{11}, \mathrm{~T}_{12}$ but significantly superior to $\mathrm{T}_{1}$.

The number of grain rows per cob varied with nutrient application as these outcomes substantiate by the findings of Bakry et al., (2009) who reported that different micronutrients and their combination was testified on maize crop which proved beneficial and salubrious in enhancing all physiological and yield parameters of maize crop and also gave a good response in terms of number of grain.

On the basis of experiment conducted by Kruczek, (2005) by applying different levels of multi-component fertilizers gave a significant effect on number of grain rows per cob.

\section{Grains per cob}

Application of nitrogen in combination with biofertilizers and zinc has increased the number of grains per cob insignificantly in this field experiment. The increment in number of grains per cob might be due to the presence of magnesium in multi-nutrients solution as grains number are direct index of pollen viability and where magnesium is proved to increase fruit set and pollen viability and significant effect on pollen formation as reported by Mahgoub et al., (2010) and Siam et al., (2008).

\section{Grain yield}

Results presented in Table 2 indicated that the highest grain yield of 7.9 t/ha was recorded with combined application of Azospirillum + $150 \mathrm{~kg} \mathrm{ha}^{-1} \mathrm{~N}+15 \mathrm{~kg} \mathrm{ha}^{-1} \mathrm{Zn}\left(\mathrm{T}_{6}\right)$ and it remained at par to Azospirillum $+120 \mathrm{~kg} \mathrm{ha}^{-1}$ $\mathrm{N}+0.5 \% \mathrm{Zn}\left(\mathrm{T}_{11}\right)$ and Azospirillum $+150 \mathrm{~kg}$ $\mathrm{ha}^{-1} \mathrm{~N}+0.5 \% \mathrm{Zn}\left(\mathrm{T}_{12}\right)$ but significantly superior to rest of the other treatments. This was followed by Azotobacter $+150 \mathrm{~kg} \mathrm{ha}^{-1} \mathrm{~N}$ $+0.5 \% \mathrm{Zn}\left(\mathrm{T}_{9}\right)$ which is statistically at par to Azotobacter $+150 \mathrm{~kg} \mathrm{ha}^{-1}+15 \mathrm{~kg} \mathrm{ha}^{-1} \mathrm{Zn}\left(\mathrm{T}_{3}\right)$, Azospirillum $+120 \mathrm{~kg} \mathrm{ha}^{-1} \mathrm{~N}+15 \mathrm{~kg} \mathrm{ha}^{-1} \mathrm{Zn}$ $\left(\mathrm{T}_{5}\right)$ and Azotobacter $+120 \mathrm{~kg} \mathrm{ha}^{-1} \mathrm{~N}+0.5 \%$ $\mathrm{Zn}\left(\mathrm{T}_{8}\right)$. Inoculation with Azospirillum resulted in significant yield increases of the magnitude 10 to $30 \%$ (Bashan et al.,) Similar findings by Hajnal-Jafari et al., (2012) who indicated that grain yield increased with inoculation by Azotobacter. The findings were also similar to Surendra and Sharanappa (2000) who observed that Azotobacter chrococcum significantly increased grain yield of maize over no inoculation.

\section{Stover yield}

Similar to grain yield, the highest stover yield was observed in Azospirillum $+150 \mathrm{~kg} \mathrm{ha}^{-1} \mathrm{~N}$ $+15 \mathrm{~kg} \mathrm{ha}^{-1} \mathrm{Zn}\left(\mathrm{T}_{6}\right)$ and was at par 
Azospirillum $+150 \mathrm{~kg} \mathrm{ha}^{-1} \mathrm{~N}+0.5 \% \mathrm{Zn}\left(\mathrm{T}_{12}\right)$ with the value $11.20 \mathrm{t} \mathrm{ha}^{-1}$ and $11 \mathrm{t} \mathrm{ha}^{-1}$, respectively. This was followed by the treatment receiving Azospirillum $+120 \mathrm{~kg} \mathrm{ha}^{-1}$ $\mathrm{N}+0.5 \% \mathrm{Zn}\left(\mathrm{T}_{11}\right)$ which recorded $9.57 \mathrm{t} \mathrm{ha}^{-1}$ and it remained at par to Azospirillum +120 $\mathrm{kg} \mathrm{ha}^{-1} \mathrm{~N}+15 \mathrm{~kg} \mathrm{ha}^{-1} \mathrm{Zn}\left(\mathrm{T}_{5}\right)$, Azotobacter $+150 \mathrm{~kg} \mathrm{ha}^{-1} \mathrm{~N}+0.5 \% \mathrm{Zn}\left(\mathrm{T}_{9}\right)$ and Azospirillum $+90 \mathrm{~kg} \mathrm{ha}^{-1} \mathrm{~N}+0.5 \% \mathrm{Zn}\left(\mathrm{T}_{10}\right)$ with the value $9.20 \mathrm{t} \mathrm{ha}^{-1}, 9.20 \mathrm{t} \mathrm{ha}^{-1}$ and 9.27 t ha ${ }^{-1}$ respectively.

\section{Economics}

The total cost of cultivation in the production of hybrid maize was found varied among the different treatments and the highest (Rs $34,567 / \mathrm{ha}$ ) as recorded in $\mathrm{T}_{6}$ and $\mathrm{T}_{3}$ followed by $T_{2}$ and $T_{5}$ with the respective values of Rs 34,2267 /ha while the lowest was found in $\mathrm{T}_{9}$ (Rs 27,687/ha). Regarding income generated, the highest gross return of Rs 115,020/ha was recorded in $\mathrm{T}_{6}$ followed by $\mathrm{T}_{12}$ (Rs 96,990 /ha) and $\mathrm{T}_{11}$ (Rs 96,327 /ha). The lowest gross return (Rs 49,370 /ha) was recorded in the treatment $\mathrm{T}_{1}$.Out of various treatments, application of Azospirillum $+150 \mathrm{~kg} / \mathrm{ha} \mathrm{N}+$ $15 \mathrm{~kg} / \mathrm{ha} \mathrm{Zn}\left(\mathrm{T}_{6}\right)$ recorded the maximum net profit (Rs $80,453 /$ ha) which was followed by $\mathrm{T}_{12}$ (Rs 66,423 /ha). The maximum B: C ratio was obtained in $\mathrm{T}_{6}$ (3.32) which was closely followed by $\mathrm{T}_{9}$ (3.20). The $\mathrm{B}$ : $\mathrm{C}$ ratio in treatment $\mathrm{T}_{1}$ (1.45) was found to be the lowest. The findings were also similar to Chandenkar et al., (2005) where cultivation of maize at $60 \times 20 \mathrm{~cm}$ spacing resulted in higher net return. The findings of Sepat and Kumar (2007) reported that higher yields of green cobs and fodder directly contributed to the returns at higher nitrogen levels.

From the above finding it can be concluded that amongst all the treatments seed treatment with Azospirillum in combination with Nitrogen $150 \mathrm{~kg} \mathrm{ha}^{-1}$ through Urea along with Zinc $15 \mathrm{~kg} \mathrm{ha}^{-1}$ through Zinc sulphate gives highest plant height at 60 DAS $(148.23 \mathrm{~cm})$, number of leaves per plant (13.67), dry weight $\left(23.10 \mathrm{~g} \mathrm{plant}^{-1}\right)$ and grain yield (7.9 t/ha) was found to be significantly higher than other varieties significantly. The highest B: C ratio was found in Treatment 6 i.e., 3.32.

\section{References}

Akbar, H., Miftahullah, M.T. Jan., A. Jan and Ihsanullah. 2002. Yield potential of sweet corn as influenced by different levels of nitrogen and plant population. Asian J. Pl. Sci. 1(6): 631-633

Asif, M., et al., 2013. Effect of nitrogen and zinc sulphate on growth and yield of maize (Zea mays L.). Journal of Agricultural Research 51(4)

Bakry M. A. A., Yasser R.A, "Soliman and S.A.M. Moussa, 2009. Importance of micronutrients, organic manure and biofertilizer for improving maize yield and its components grown in desert sandy soil," Research Journal of Agriculture and Biological Sciences, Vol. 5, No. 1, pp. 16-23.

Bashan, Y., Holguin LE 2004. Azospirillumplant relationships: physiological, molecular, agricultural and environmental advances.Can.J.Microbiol.50:521-577.

Braccini, A.L., et al., 2012. Seed Inoculation with Azospirillum brasilense associated with the use of Bioregulators in Maize. Revista Caatinga, 25(2): 58-64.

Carlettie, S., 2002. Use of growth-promoting rhizobacteria in plant micropropagation.www. Ag. Auburn. Edu.

Cavallet, L.E., Pessoa, A.C.D.P. and Helmich, J.J., 2000. Corn productivity in response to nitrogen application and seed inoculation with Azospirillum spp. Revista Brasileira de Engluharia Agricola I Ambiental, 4(1): 129-132.

Chandenkar, M.M., et al., 2005. Ann. Plant 
Physiol., 19 (2): 172-174

Cohen, E., Okon, Y., Kigel, J., Nur, I and Henis, Y. 1980. Increase in dry weight and total nitrogen content in Zea mays and Setaria italic associated with nitrogen fixing Azospirillum species. Plant Physio. 66: 746-749.

El Noeman, A.A., El-Halem, A.K.A., ElZeiny, H.A., 1990. Response of maize (Zea mays L.) to irrigation intervals under different levels of nitrogen fertilization. Egyptian J. Agron. 15 (12), 147-158.

Fallik E., Okon Y., Fischer, M., 1988. Growth response of maize roots to Azospirillum inoculation: effect of soil organic matter content, number of rhizosphere bacteria and timing of inoculation. Soil Biol Biochem 20, 45-49.

Forlain, G., Pastorelli, R., Branzoni, M. and Favilli, F. 1998. Root colonization efficiency, plant growth promoting activity and potentially related properties in plant associated bacteria. Journal of Genetics and Breeding 49: 343-351.

Gasim, S.H., 2001. Effect of nitrogen, phosphorus and seed rate on growth, yield and quality of forage maize (Zea mays L.).M.Sc. Thesis, Faculty of Agric., Univ. Of Khartoum.

George, R., and M. Schmitt. (2002). Zinc for crop production. Reagents of the University of Minnesota.

Hajnal-Jafari T., Latkovic, D., Duric, S., Mrkovacki, N., Najdenovska. O. 2012. The use of Azotobacter in organic maize production. Research Journal of Agricultural Science, 44(2): 28-32.

Iqbal, A., Ayoub. M., Zaman, H.And Ahmed, R. 2006. Impact of nutrient management and legumes association on agro qualitative traits of maize forage Pak. J.Bot. 38, 1079-1084.

Kara, S. M., M. Deveci, O. Dede and N. Sekeroglu, 1999. The Effects of
Different Plant Densities and Nitrogen Levels on Forage Yield and Some Attributes in Silage Corn. Turkey 3. Field Crops Congress, 1-18 November 1999, Adana, pp. 172-177.

Karasu, A., 2012. Effect of nitrogen levels on grain yield and some attributes of some hybrid maize cultivars (Zea mays indentata Sturt.) grown for silage as second crop. Bulg. J. Agric. Sci., 18: 4248

Kruczek, A., 2005. 'Effect of Nitrogen Doses and Application Ways of Nitrogen Fertilizers and a Multi-Component Fertilizer on Maize Yielding," Pam. Pul. Poland. Vol. 140 pp. 129-138.

Kumar, P., Desai, B.K. and Pujari, B.T. 2007. Effect of Integrated Nutrient Management on Economics of Maize Cultivation. Karnataka J. Agric. Sci., 20(4): 831-832.

Mahgoub, M., H., El-Quesni, Fatima E. M. and Kandil M.M. 2010. "Response of Vegetative Growth and Chemical Constituents of Schefflera arboricola L. Plant to Foliar Application of Inorganic Fertilizer (Grow-More) and Ammonium Nitrate at Nubaria." Ozean Journal of Applied Science, Vol. 3, pp. 177-184.

Monib, M., Abd-el-Malek, Y., Hosny, I. and Fayez, M. 1979. Effect of Azotobacter inoculation on plant growth and soil nitrogen. Zentralbi Bakteriol Naturwiss, 134: $140-148$.

Omara, H.A., 1989. The effect of spacing, nitrogen and phosphorus application on growth and yield of maize (Zea mays L.). M.Sc. Thesis, Univ. of Khartoum, Faculty of Agric.

Puente, Mariana L., Garcia Julia E. and Alejandro Perticari 2009. Effect of the Bacterial Concentration of Azospirillum brasilense in the Inoculum and its Plant Growth Regulator Compounds on Crop Yield of Corn (Zea mays L.) In the Field. World Journal of Agricultural 
Sciences 5(5): 604-608.

Raju M. S., Srinivas A. and Raja V. 1997. Performance of promising pre-release maize varieties at different nitrogen levels under rainfed conditions. Annals of Arid Zone. 36 (4): 377-379.

Rasheed, M., H. Ali and T. Mahmood. 2004. Impact of nitrogen and sulfur application on growth and yield of maize crop. Pak. J. Sci. Res. 15(2): 153157.

Ritchie, W.S., John, J. Hanway, Garreno, B., 1993. How a corn plant develop. Special report No. 48, Iowa State Univ. of Science and Technology, Cooperative Extension Service.

Sawi, S.M.A., 1993. The effect of nitrogen, phosphorus and time of application on growth and yield of maize of Agric. Univ. of Khartoum.
Sepat, S., and Kumar, A. 2007. Nitrogen managent in maize (Zea mays) under lifesaving and assured irrigation. Indian J. Agric. Sci., 77(7): 451-59.

Sharma, R.K., 1973. Response of maize to nitrogen fertilization. Madras Agric. J. 60, 399-440.

Surendra, S.T., and Sharanappa, 2000. Integrated management of nitrogen and Phosphorous in maize (Zea mays L.,) and their respect on cowpea (Vigna unguiculata).Indian Journal of Agricultural Sciences 119-121.

Tilak, K.V., B.R., Singh, C.S., Roy, N.K. and Rao, Subha, N.S. 1992. Azospirillum brasilense and Azotobacter enoculum effect on maize and sorghum. Soil Biochemical14:419-428.

\section{How to cite this article:}

Evangeline Marngar and Joy Dawson. 2017. Effect of Biofertilizers, Levels of Nitrogen and Zinc on Growth and Yield of Hybrid Maize (Zea mays L.). Int.J.Curr.Microbiol.App.Sci. 6(9): 3614-3622. doi: https://doi.org/10.20546/ijcmas.2017.609.444 